\title{
Reafirmasi Sistem Pemerintahan Presidensial dan Model Pertanggungjawaban Presidensial dalam Perubahan UUD 1945: Penelusuran Sebab dan Konsekuensi
}

\author{
Bilal Dewansyah* dan M. Adnan Yazar Zulfikar**
}

\begin{abstract}
Abstrak
Perubahan Ketiga UUD 1945 pada tahun 2001 menegaskan reafirmasi terhadap sistem presidensial. Namun dalam proses Perubahan UUD 1945 berkembang juga semangat pembatasan kekuasaan Presiden dengan memberikan kewenangan lebih kepada DPR sebagai lembaga legislatif, sebagaimana tercermin dalam Perubahan Pertama UUD 1945. Setelah perubahan, Presiden tidak lagi memiliki pertanggungjawaban politik. Hal tersebut melatarbelakangi dua permasalahan: Pertama, mengapa perubahan UUD 1945 menetapkan pilihan politik untuk melakukan reafirmasi terhadap sistem presidensial. Kedua, bagaimana konsekuensi perubahan tersebut pada pertanggungjawaban Presiden. Tulisan ini bertujuan untuk menjawab kedua permasalahan tersebut: Pertama, menyelidiki sebab reafirmasi sistem presidensial pada perubahan UUD 1945. Kedua, menggambarkan konsekuensi perubahan UUD 1945 pada sistem pertanggungjawaban Presiden dan Wakil Presiden. Tulisan ini akan dimulai dengan pembahasan pengantar mengenai perdebatan teoritis sistem pemerintahan, kemudian dilanjutkan dengan pembahasan sebab pilihan reafirmasi sistem presidensial dan pertanggungjawaban Presiden setelah perubahan UUD 1945. Hasil kajian tulisan ini menunjukan bahwa reafirmasi sistem presidensial dalam UUD 1945 dilatarbelakangi semangat membentuk pemerintahan yang stabil, namun juga dengan semangat membatasi kekuasaan Presiden, sehingga diberikan kekuasaan lebih kepada legislatif. Pengalaman masa lalu tentang kegagalan sistem parlementer juga menjadi alasan reafirmasi sistem presidensial. Perubahan UUD 1945 juga berkonsekuensi pada perubahan sistem pertanggungjawaban Presiden. Setelah perubahan UUD 1945, pertanggungjawaban yang dapat memberhentikan Presiden hanya melalui impeachment.
\end{abstract}

Kata kunci: pertanggungjawaban presiden, perubahan UUD 1945, reafirmasi, sistem presidensial, sistem pemerintahan.

\section{Reaffirmation on Presidential Form of Government and Presidential Accountability System on Constitutional Amendments: The Search for Cause and Consequences}

\section{Abstract}

The Third Amendment of the 1945 Constitution has reaffirm presidential form of government. During the amendments, there is also spirit to restrict Presidential power by

PADJADJARAN Jurnal IImu Hukum Volume 3 Nomor 2 Tahun 2016 [ISSN 2460-1543] [e-ISSN 2442-9325]

* Dosen Fakultas Hukum Universitas Padjadjaran, Jl. Dipati Ukur No. 35 Bandung, b.dewansyah@unpad.ac.id, S.H., M.H. (Universitas Padjadjaran).

** Peneliti pada Pusat Studi Kebijakan Negara Fakultas Hukum Universitas Padjadjaran, Jl. Imam Bonjol No. 21 Bandung, adnyzr@gmail.com, S.H. (Universitas Padjadjaran). 
enumerating more powers to the DPR as the legislature. After the 1945 Constitution amendment, President does not have the means of political accountability. It raises two issues: First, why did 1945 Constitutional amendments choose to reaffirm presidential system and second, how the consequences of these amendments in the term of Presidential accountability. This paper aims to address both issues: First, investigating the reason of presidential system reaffirmation in 1945 Constitutional amendment. Second, describing the consequences of the 1945 Constitutional amendments to the presidential accountability system. This paper will begin with an introduction on type of government theoretical debate, and followed by an analysis of the reason behind presidential system reaffirmation in 1945 constitution amendment and the presidential accountability after these change. This paper shows that presidential system reaffirmation in 1945 constitutional amendments was motivated by the spirit to form a stable government with the spirit to limit presidential power in the same time, so it was done by enumerating more power to the legislature. After 1945 constitutional change, President can be dismissed only by impeachment.

Keywords: presidential accountability, 1945 Constitution Change, reaffirmation, presidential system, governmental system.

\section{A. Pendahuluan}

Perubahan Ketiga Undang-Undang Dasar 1945 (UUD 1945) di tahun 2001 memberikan arti tersendiri bagi keberadaan Lembaga Kepresidenan sebagai pemegang kekuasaan eksekutif. Dipilihnya Presiden dan Wakil Presiden secara langsung oleh rakyat $^{1}$ menyebabkan hilangnya pertanggungjawaban politik Presiden kepada Majelis Permusyawaratan Rakyat (MPR). Hal ini diperkuat dengan dihapuskannya Penjelasan UUD 1945 secara implisit, ${ }^{2}$ sehingga peran Presiden sebagai mandataris MPR juga tidak lagi berlaku. Beberapa aspek dari sistem presidensial yang dianut lebih murni dibandingkan dengan sebelum Perubahan UUD 1945. ${ }^{3} \mathrm{Hal}$-hal tersebut mencerminkan reafirmasi terhadap sistem presidensial atau dikenal dengan prinsip penguatan sistem presidensial.

Adanya pengaturan Pasal 7A Perubahan Ketiga UUD 1945, mengenai pemberhentian Presiden dan Wakil Presiden dalam masa jabatannya, mencerminkan pertanggungjawaban Lembaga Kepresidenan tidak lagi bersifat politis, ${ }^{4}$ melainkan bersifat hukum. Namun demikian, karena akhir pertanggungjawaban

1 Lihat Pasal 6A Perubahan Ketiga Undang-Undang Dasar 1945 (UUD 1945) dan dihapuskannya Penjelasan UUD 1945.

2 Dalam Perubahan Pertama-Empat UUD 1945, Penjelasan UUD 1945 tidak pernah dihapus secara tegas. Namun demikian, dengan ditetapkannya UUD 1945 yang hanya terdiri dari pasal-pasal dan pembukaan, maka Penjelasan UUD 1945 secara implisit dihapuskan dalam struktur UUD 1945. Lihat Pasal II Aturan Tambahan Perubahan Keempat UUD 1945.

3 Sebelum Perubahan UUD 1945, Sri Soemantri mengatakan sistem pemerintahan Indonesia adalah sistem campuran (kombinasi) (Presidensial dan Parlementer - pen). Lihat Sri Soemantri, Sistem-Sistem Pemerintahan Negara-Negara ASEAN, Bandung: Penerbit Tarsito, 1976, hlm. 56.

4 Lihat Pasal 7A Perubahan Ketiga UUD 1945. 
yang bersifat hukum tersebut ada pada Sidang Umum MPR, sifat pertanggungjawaban tersebut tidak lagi bersifat hukum, melainkan pertanggungjawaban politis. Terlepas dari persoalan pertanggungjawaban hukum yang berakhir pada keputusan MPR sebagai lembaga politik, pertanggungjawaban Presiden dan Wakil Presiden tidak lagi didasarkan pada alasan-alasan yang sifatnya kebijakan (policy). Kebijakan Lembaga Kepresidenan, sekalipun itu bertentangan dengan UUD 1945, tidak dapat dijadikan alasan pemberhentian Presiden dan/atau Wakil Presiden.

Dalam Perubahan Ketiga UUD 1945 tidak dikenal lagi pertanggungjawaban atas dasar kebijakan, akan tetapi secara teoritis Presiden dan Wakil Presiden (pemerintah) bertanggungjawab kepada pihak yang memilihnya (electorates). ${ }^{5}$ Dari hasil penelitian penulis sebelumnya, perwujudan pertanggungjawaban politik Presiden dan Wakil Presiden dalam sistem pemerintahan Indonesia setelah Perubahan UUD 1945 adalah kepada rakyat melalui pemilihan umum (pemilu). ${ }^{6}$

Permasalahan pertanggungjawaban eksekutif dalam sistem pemerintahan presidensial Indonesia masih menimbulkan masalah dalam praktik. Misalnya, ketika terjadi beberapa kali demonstrasi menuntut pembatalan kenaikan harga bahan bakar minyak (BBM), terutama pada masa pemerintahan Susilo Bambang Yudhoyono (SBY) dan Jusuf Kalla, rakyat sebagai pihak yang memilih pejabat dalam Lembaga Kepresidenan tidak dapat melakukan pengawasan yang berarti. Walaupun kemudian Dewan Perwakilan Rakyat (DPR) menggunakan hak angket pada tahun 2008, akan tetapi hal tersebut tidak dapat dijadikan dasar untuk memberhentikan Presiden dan Wakil Presiden.

Begitu pula dengan penggunaan hak angket pada periode kedua Presiden SBY (bersama Wakil Presiden Boediono) untuk menyelidiki beberapa kebijakan strategis pemerintah, seperti kenaikan harga BBM dan bail-out Bank Century, tidak menyebabkan Presiden dan/atau Wakil Presiden jatuh dari jabatannya. Ini mencerminkan bahwa DPR memiliki kecenderungan untuk mengendalikan kebijakan Presiden dengan menggunakan pranata hak-hak pengawasan yang diatur dalam Perubahan UUD 1945, namun tidak dapat menyebabkan Presiden dan/atau Wakil Presiden diberhentikan dari jabatannya, karena ada perubahan model pertanggungjawaban presiden sebagaimana dikemukakan di atas.

$\mathrm{Hal}$ tersebut berbeda dengan sistem pemerintahan parlementer yang menganut paham pertanggungjawaban menteri. Dalam sistem pemerintahan tersebut, Perdana Menteri dan anggota Kabinet dapat diberhentikan oleh badan

5 Herbert J. Spiro, Responsibility in Government: Theory and Practice, New York: Van Nostrand Reinhold Company, 1969, hlm. 4.

$6 \quad$ Penilaian rakyat pemilih kepada Wakil Presiden bersama Presiden akan terlihat dalam Pemilu Presiden dan Wakil Presiden berikutnya. Lihat Bilal Dewansyah, "Pertanggungjawaban Wakil Presiden Dalam Sistem Pemerintahan Indonesia Setelah Perubahan UUD 1945", Skripsi, Fakultas Hukum Universitas Padjadjaran, Bandung, 2006, hlm. 170. 
legislatif jika badan legislatif menarik dukungannya. ${ }^{7}$ Indonesia sendiri pernah menerapkan sistem pemerintahan parlementer dalam kurun waktu 1945-1959. ${ }^{8}$ Kabinet parlementer pada masa itu tidak stabil yang ditandai dengan pergantian kabinet dalam jangka waktu yang pendek. Setelah kembali ke UUD 1945 melalui Dekrit Presiden 5 Juli 1959, sistem pemerintahan parlementer ditinggalkan. Setelah itu, sistem pemerintahan Indonesia lebih memperlihatkan segi-segi presidensial, walaupun menurut Sri Soemantri, tidak murni sistem presidensial namun sistem pemerintahan campuran. ${ }^{9}$

Dalam proses perubahan UUD 1945, sistem pemerintahan parlementer tidak menjadi pertimbangan untuk dianut kembali. Hal ini terlihat dari kesepakatan Panitia Ad-Hoc (PAH) III Badan Pekerja MPR dalam proses perubahan UUD 1945 yang salah satunya adalah mempertegas sistem pemerintahan presidensial. ${ }^{10}$ Hasilnya, Perubahan Ketiga UUD 1945 mempertegas keberadaan sistem pemerintahan presidensial, walaupun dalam hal pembentukan undang-undang (UU) masih mencerminkan aspek parlementer."11

Dianutnya sistem pemerintahan presidensial dalam UUD 1945 dan diatur lebih murni dalam Perubahan Ketiga UUD 1945 masih menimbulkan permasalahan terkait dengan praktik pertanggungjawaban politik Presiden. Oleh karena itu, artikel ini membahas dua persoalan pokok dan diskursus ini. Pertama, mengenai mengapa Perubahan Ketiga UUD 1945 me-reafirmasi kembali sistem presidensial, padahal ada kecenderungan untuk membatasi kekuasaan presiden pada Perubahan Pertama UUD 1945. Kemudian yang kedua, mengenai bagaimana pertanggungjawaban politik Presiden, jika sebelum Pemilu berikutnya, Presiden kehilangan dukungan rakyat karena melakukan kebijakan yang bertentangan dengan konstitusi atau kehendak rakyat.

7 Salah satu ciri sistem parlementer menurut Allan R. Ball adalah "The political executive, the prime minister, the chancellor, etc, together with the cabinet, is part of legislature, and can be removed by the legislature if the legislature withdraws it support". Allan R. Ball dalam Sri Soemantri, Sistem-Sistem......, Op.cit., hlm. 32. Lihat Ismail Suny, Pergeseran Kekuasaan Eksekutif Suatu Penyelidikan Dalam Hukum Tata Negara, Jakarta: Aksara Baru, 1981, hlm. 31.

9 Sri Soemantri, Sistem-Sistem..., Loc.cit.

10 Setjen MPR RI, Panduan Pemasyarakatan Undang-Undang Dasar Negara Republik Indonesia 1945, Jakarta: Setjen MPR RI, 2006, hlm. 13.

11 Sistem presidensial yang awalnya diterapkan pertama kali di Amerika Serikat berdasar pada prinsip pemisahan kekuasaan dengan modifikasi check and balances system: "Presidential government often associated with the theory of the separation of powers which is popular in eighteenth century when the American constitution was framed". Lihat Douglas V. Verney, "Parliamentary Government and Presidential Government", dalam Parlimanetary Versus Presidential Government yang disusun oleh Arend Lipjhart (eds), New York: Oxford University Press, 1992, hlm. 38. Konsekuensinya, pelaksanaan kekuasan eksekutif, legislatif, dan yudikatif terpisah. Sementara itu, UUD 1945 setelah perubahan masih memberikan kewenangan kepada Presiden untuk mengajukan rancangan undang-undang (RUU) dan memberikan persetujuan atas RUU yang diajukan DPR (lihat Pasal 5 ayat (1) dan Pasal 20 ayat (2) Perubahan Pertama UUD 1945). 


\section{B. Perdebatan Teoritis Sistem Pemerintahan}

Arend Lijphart memaparkan sejumlah keuntungan dan kekurangan baik dalam sistem presidensial maupun parlementer dari 34 tulisan para ahli dalam buku yang disuntingnya, Parliamentary Versus Presidential Government. ${ }^{12}$ Perdebatan antara sistem presidensial dan sistem parlementer berkisar pada 3 (tiga) keuntungan dan kerugian utama dari kedua sistem pemerintahan tersebut. ${ }^{13}$ Sistem presidensial memiliki 3 (tiga) keuntungan utama dalam penerapannya, yaitu stabilitas pemerintahan (executive stability), dianggap dapat mewujudkan demokrasi yang lebih baik (greater democracy), dan pemerintahan yang terbatas (limited government).$^{14}$ Kerugian yang muncul dari sistem presidensial adalah terjadinya kebuntuan hubungan eksekutif-legislatif (executive-legislative deadlock), kekakuan dari segi waktu (temporal rigidity), prinsip 'pemenang meraih segalanya' (winner take all). ${ }^{15}$ Sementara itu, keuntungan penerapan sistem presidensial dianggap sebagai kerugian penerapan sistem parlementer dan begitu pula sebaliknya. ${ }^{16}$

Keuntungan pertama dari sistem presidensial adalah pemerintahan yang stabil (executive stability) berdasarkan prinsip masa jabatan presiden yang tetap (fixed term of office). Kebalikannya, sistem parlementer dianggap dapat menciptakan pemerintahan yang tidak stabil (instability government), dengan penggunaan mosi tidak percaya (vote of no convidence) oleh legislatif yang menyebabkan jatuhnya kabinet. ${ }^{17} \mathrm{Hal}$ ini misalnya terjadi di Perancis pada masa Republik Ketiga dan berlanjut pada masa Republik Keempat. ${ }^{18}$ Bagi para pendukung sistem parlementer, dengan pengunaan mosi tidak percaya justru dianggap sebagai sebuah fleksibilitas dalam menghadapi perubahan situasi, sementara sistem presidensial bersifat rigid, tidak mudah beradaptasi dengan perubahan situasi. ${ }^{19}$

Kecuali di Amerika Serikat (AS), penerapan sistem presidensial di beberapa negara menunjukkan pemerintahan yang tidak stabil, misalnya di negara-negara Amerika Latin pada Abad ke-19 di mana terjadi pergantian pemerintahan dari corak demokrasi ke diktator atau sebaliknya. ${ }^{20}$ Salah satu sebab munculnya ketidakstabilan pemerintahan dalam sistem presidensial adalah penerapan sistem multi partai. Seperti dikatakan oleh Mainwaring, kombinasi sistem presidensial dan

\footnotetext{
Arend Lipjhart, "Introduction", dalam Arend Lipjhart (eds), Parliamentary..., Op.cit., hlm. 11.

Ibid.

Ibid.

Ibid.

Ibid.

Ibid.

Catherine Elliot (et.al.), French Legal System, England: Pearson Education Limited, 2006, hlm. 14-15.

Lihat Juan Linz, "The Perils of Presidentialism", dalam The Democracy Source Book yang disusun oleh Robert A. Dahl (et.al.) (eds), Cambridge: The MIT Press, 2003, hlm. 263.

20 Lihat dalam Jose Antonio Cheibub, Presidentialism, Parliamentarism, and Democracy, Cambridge: Cambridge University Press, 2006, hlm. 1.
} 
sistem multi partai tidak sesuai dengan demokrasi yang stabil. ${ }^{21} \mathrm{Hal}$ ini disebabkan kombinasi tersebut menciptakan kesulitan-kesulitan dalam hubungan antara presiden dan kongres (badan perwakilan). Hubungan eksekutif-legislatif yang tidak harmonis sering terjadi jika presiden berasal dari partai politik yang berbeda dengan partai politik yang menguasai kursi badan perwakilan. ${ }^{22}$ Karena hubungan yang tidak harmonis dengan Kongres, semua Presiden Chili dari mulai Jorge Alessandri hingga Salvador Allende mengesampingkan kewenangan Kongres atau mekanisme perubahan konstitusi untuk memperluas kewenangannya. ${ }^{23} \mathrm{Hal}$ yang sama juga terjadi di Colombia pada tahun 1968 dan Uruguay pada tahun 1967. ${ }^{24}$

Menurut Mainwaring, salah satu langkah yang dapat dilakukan untuk mengatasi masalah sistem presidensial multi partai adalah dengan membentuk pemerintahan koalisi (coalition government), namun hal itu lebih sulit dilakukan dibandingkan dengan sistem parlementer. ${ }^{25}$ Dalam sistem parlementer multi partai, koalisi partai politik untuk membentuk pemerintahan dibutuhkan ketika tidak ada partai tunggal yang mendapatkan suara mayoritas. ${ }^{26}$ Namun demikian, pengalaman Indonesia antara tahun 1945-1959, sistem parlementer multi partai yang tidak pernah menciptakan partai politik dengan suara mayoritas menyebabkan pergantian kabinet berkali-kali. ${ }^{27}$

Keuntungan kedua dari sistem presidensial, kepala pemerintahan (presiden) yang dipilih oleh rakyat (popular election) dianggap lebih demokratis dibandingkan dengan cara pemilihan secara tidak langsung yang terjadi dalam sistem parlementer. ${ }^{28}$ Namun demikian, dalam sistem parlementer khususnya dalam sistem dua-partai, para pemilih biasanya memilih partai (untuk pemilihan parlemen), secara tidak langsung memilih ketua partai politik sebagai perdana menteri. ${ }^{29}$ Persoalannya, dalam sistem parlementer yang juga menerapkan sistem multi partai, pemilihan perdana menteri mensyaratkan adanya tawar-menawar antar partai. ${ }^{30} \mathrm{Hal}$ ini dianggap satu kelemahan sistem parlementer karena perubahan kabinet dapat terjadi antara pemilihan ke pemilihan selanjutnya dan tidak disertai pelibatan pemilih (popular involvement). ${ }^{31}$ Namun demikian, di Jerman dan Belanda karena ketidakpuasan dalam sistem parlementer multi partai,

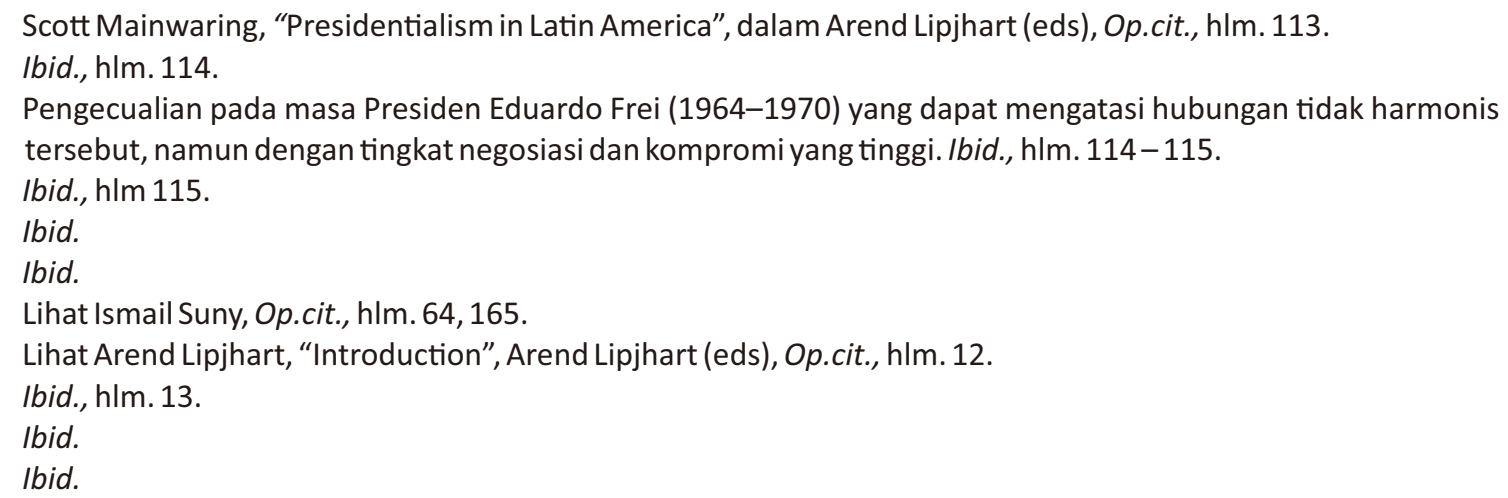


maka setiap perubahan mendasar dalam komposisi kabinet harus dilakukan pemilihan ulang (anggota parlemen). ${ }^{32}$

Ketiga, dengan dianutnya prinsip pemisahan kekuasaan (separation of power) dalam sistem presidensial, berarti pemerintah bersifat terbatas (limited government), yaitu perlindungan kebebasan individual terhadap pemerintahan tirani. Di lain pihak, sistem parlementer dianggap tidak memenuhi kriteria tersebut. Misalnya dikatakan oleh Schlesinger bahwa kasus Watergate hanya mungkin terungkap dalam sistem presidensial. ${ }^{33}$

Para pendukung sistem parlementer tidak setuju dengan pendapat bahwa sistem parlementer mengancam kebebasan individual. Adanya peradilan yang bebas, oposisi parlementer yang vokal dan memberi peringatan, serta kabinet koalisi muti partai memberikan perlindungan hak-hak individu dari penyalahgunaan kekuasaan oleh pemerintah. ${ }^{34}$ Dari sejarahnya di Inggris, adanya peralihan kekuasaan pemerintahan dari Raja pada parlemen juga mencerminkan prinsip pemerintahan yang terbatas. Dengan demikian, baik sistem presidensial maupun parlementer memiliki cara-cara yang berbeda mengimplementasikan gagasan pemerintahan yang terbatas (limited government-constitutionalism).

Sementara itu, terdapat 3 (tiga) kekurangan jika sistem presidensial diterapkan. Pertama, konflik antara eksekutif-legislatif yang dapat menyebabkan kebuntuan (deadlock). Ketika terjadi ketidaksepakatan antara eksekutif dan legislatif, tidak ada cara yang secara institusional dapat menyelesaikannya, berbeda dengan penentu kepercayaan legislatif dalam sistem parlementer yang menjaga keseimbangan eksekutif dan legislatif.

Kekurangan kedua dalam sistem presidensial adalah kekakuan dari segi waktu (temporal rigidity). Seperti telah disinggung sebelumnya, hal ini disebabkan sistem masa jabatan yang tetap (fixed term office), yang menurut Juan Linz, "menyebabkan ketidakberlanjutan proses politik". ${ }^{35}$ Misalnya ketika Presiden mengeluarkan kebijakan yang bertentangan dengan konstitusi sehingga menimbulkan krisis, lembaga legislatif tidak dapat memberhentikan Presiden dalam masa jabatannya. Pemberhentian Presiden dalam masa jabatannya hanya dapat dilakukan melalui prosedur seperti impeachment yang didasarkan pada alasan-alasan yang bersifat hukum. Hal ini disebabkan Presiden dalam sistem presidensial dianggap bertanggung jawab kepada konstitusi secara hukum. ${ }^{36}$ Sementara itu, secara politik Presiden (dan Wakil Presiden) dianggap bertanggung jawab kepada pemilih

\footnotetext{
32 Ibid. Hal yang sama, namun diatur secara tertulis, diatur dalam Pasal 84 UUDS 1950 yang rumusannya adalah "Presiden berhak membubarkan DPR. Keputusan Presiden yang menyatakan pembubaran itu, memerintahkan pula untuk mengadakan pemilihan DPR baru dalam 30 hari".

33 Arthur M. Schlesinger, Jr, "Leave The Constitution Alone”, dalam Arrend Lipjhart (eds), Ibid., hlm. 92.

34 Arrend Lipjhart, "Introduction", Ibid., hlm. 14-15.

35 Juan Linz, "Perils...", dalam Robert A. Dahl (et.al.) (eds), Op.cit., hlm. 259.

36 Douglas V. Verney, "Parliamentary...", dalam Arend Lipjhart (eds), Op.cit., hlm. 43.
} 
(rakyat). ${ }^{37}$ Dengan dipilihnya Presiden (dan Wakil Presiden) oleh rakyat (atau badan pemilih) begitu pula badan legislatif, maka kedua-duanya dianggap sama-sama mewakili rakyat. ${ }^{38}$

Kekurangan ketiga adalah dasar yang digunakan dalam sistem presidensial adalah prinsip 'pemenang meraih segalanya' (winner-take-all). Dalam pemilihan Presiden (dan Wakil Presiden), hanya satu (pasang) kandidat dan satu partai (dalam sistem dua partai) yang dapat menang, sementara kandidat yang lainnya dianggap kalah.

Penerapan kedua sistem pemerintahan tersebut dalam praktik bernegara sangat berbeda. Ada negara yang stabil menerapkan sistem presidensial ada juga yang tidak. Sebaliknya, ada negara relatif stabil menerapkan sistem parlementer ada juga yang tidak. Menurut Seymour Martin Lipset hal tersebut disebabkan oleh perbedaan budaya politik. ${ }^{39}$ Oleh karena itu, setiap negara menghadapi masalahmasalah yang berbeda-beda dalam sistem pemerintahannya. Ada pula negara yang pada akhirnya tidak memilih untuk mengikuti secara mutlak sistem presidensial atau sistem parlementer. Misalnya Perancis yang sejak tahun 1958 (Republik Kelima) menerapkan sistem dual-executive di mana kekuasaan eksekutif dibagi antara Presiden dan Perdana Menteri (beserta menteri-menteri lainnya).$^{40} \mathrm{Hal}$ yang serupa juga terjadi di Swiss yang menerapkan sistem collegial executive di mana kekuasaan eksekutif berada di tangan Federal Council. ${ }^{41}$

\section{Alasan Pemilihan Kembali Sistem Presidensial dalam Perubahan UUD 1945}

Kenyataan yang terjadi pada Perubahan Pertama UUD 1945 yang dibahas dan dirancang oleh PAH III BP MPR, upaya untuk meniadakan executive heavy tidak mencerminkan prinsip check and balances, akan tetapi lebih mencerminkan legislative heavy. ${ }^{42}$ Ada perubahan beberapa pasal dalam UUD 1945 yang memasukkan kewenangan DPR dalam beberapa kewenangan Presiden yang sebelumnya dianggap sebagai lingkup kekuasaan eksekutif, misalnya Pasal 13 ayat (2), Pasal 13 ayat (3), dan Pasal 14 ayat (2) Perubahan Pertama UUD 1945.

Pertimbangan DPR dalam pengangkatan duta juga diatur dalam Konstitusi AS. Persoalannya, sebagaimana dikatakan Bagir Manan, apakah hal tersebut juga berlaku bagi diplomat karir yang memang bertugas mewakili negara RI? Persoalan

\footnotetext{
lbid., hlm. 45.

38 Bahkan menurut Verney, Presiden mungkin dapat mengatakan pada badan legislatif: "You represent your constituency: I represent the whole people". Ibid.

39 Seymour Martin Lipset, "The Centrality of Political Culture”, dalam Arend Lipjhart (eds), Op.cit., hlm. 209.

40 Chaterine Elliot (et. al.), Op.cit., hlm. 35.

41 Arend Lipjhart, "Introduction" dalam Arend Lipjhart (eds), Op.cit., hlm. 7.

42 Ni'matul Huda, Politik Ketatanegaran Indonesia Kajian Terhadap Dinamika Perubahan UUD 1945, Yogyakarta: FH UII Press, 2003, hlm. 18, 86. Lihat pula Bagir Manan, "Beberapa Persoalan Paradigma Setelah atau Akibat Perubahan UUD 1945", Jurnal Konstitusi PSKN FH Unpad, Volume II, Nomor 2, 2010, hlm. 32.
} 
lain yaitu ukuran baku untuk menetapkan seseorang cakap atau tidak cakap menjadi duta. ${ }^{43}$ Pertimbangan DPR dalam menerima duta negara lain, merupakan ketentuan yang berlebihan. Menurut Bagir Manan, hal tersebut merupakan praktik yang tidak lazim karena berkaitan dengan kedaulatan negara asing (untuk mengangkat warga negaranya menjadi duta di negara penerima). ${ }^{44}$

Dalam buku Panduan Memasyarakatkan UUD Negara RI yang disusun Setjen MPR, latar belakang munculnya pertimbangan DPR dalam menerima duta negara lain dimaksudkan agar pemerintah tidak disalahkan apabila menolak duta asing yang diajukan oleh negara lain karena telah ada pertimbangan DPR. ${ }^{45} \mathrm{Hal}$ ini bertentangan dengan sifat dari pertimbangan DPR yang tidak mengikat secara yuridis. Lagi pula, praktiknya tidak pernah ada penolakan Presiden bagi duta yang ditempatkan oleh negara lain. ${ }^{46}$ Berbeda jika negara yang bersangkutan tidak memiliki hubungan diplomatik dengan Indonesia, seperti misalnya Israel di mana tidak ada alasan untuk menempatkan seseorang menjadi duta di Indonesia.

Pertimbangan DPR dalam pemberian amnesti dan abolisi juga dinilai tidak tepat. Hal ini disebabkan bahwa amnesti dan abolisi tidak hanya berkaitan dengan pidana politik, sehingga kalau pun dibutuhkan semacam pertimbangan, cukup dari Mahkamah Agung (MA), karena berkaitan dengan kekuasaan presiden di bidang yustisial. ${ }^{47}$ Dalam proses Perubahan Pertama UUD 1945, hampir semua fraksi di MPR bersepakat untuk membatasi kekuasaan Presiden, meskipun masih dalam koridor sistem presidensial. ${ }^{48}$ Namun yang menarik adalah pendapat dari F-PBB melalui juru bicaranya Hamdan Zoelva yang menerangkan pembatasan kekuasaan Presiden dalam konteks check and balances system. ${ }^{49}$

Pembatasan kekuasaan Presiden memang terlihat jelas dalam Pasal 13, Pasal 14, dan Pasal 17 ayat (4) Perubahan Pertama UUD 1945. Persoalannya, pembatasan kekuasaan Presiden khususnya dalam hal pembentukan UU masih menggunakan logika dari UUD 1945 sebelum perubahan, bahwa pembentukan UU masih merupakan kekuasaan bersama antara Presiden dan DPR. Hal ini misalnya diungkapkan oleh sebagian besar anggota MPR. Salah satunya adalah dikatakan oleh F-FKB melalui juru bicaranya, Gregorius Seto Haryanto yang menyatakan

\footnotetext{
43 Bagir Manan, Lembaga Kepresidenan, edisi revisi, Yogyakarta: FH UII Press, 2006, hIm. 173.

44 Ibid.

45 Setjen MPR-RI, Op.cit., hlm. 73.

46 Penarikan duta besar pertama RRC, Wang Yen-shu pada tahun 1950 karena melakukan kampanye untuk menarik orientasi orang-orang Cina di Indonesia untuk kembali ke RRC, dilakukan oleh RRC sendiri, bukan atas penolakan Indonesia. Lihat Koerniatmanto Soetoprawiro, Hukum Kewarganegaraan dan Keimigrasian Indonesia, Jakarta: Gramedia Pustaka Utama, 1994, hIm. 104.

47 Lihat Bagir Manan, Lembaga..., Op.cit., hlm. 161.

48 Lihat dalam Tim Penyusun, Naskah Komprehensif Perubahan Undang-Undang Dasar Negara Republik Indonesia Tahun 1945: Latar Belakang, Proses, dan Hasil Pembahasan 1999-2002, Jakarta: Setjen MK-RI, 2008, hlm. 67-71.

49 Ibid., hlm. 68.
} 
bahwa: "dalam Pasal 5 ayat (1) ini seolah-olah DPR hanya menyetujui begitu, tetapi Pasal 5 ayat (1) ini bisa diubah bahwa Presiden bersama DPR memegang kekuasaan. Jadi bukan hanya sekedar persetujuan DPR". ${ }^{50} \mathrm{Hal}$ yang sama juga diungkapkan oleh F-KKI. ${ }^{51}$ Sementara itu, F-PDIP mengusulkan perubahan Pasal 5 ayat (1), dengan rumusan "Presiden berhak mengajukan Rancangan Undang-Undang (RUU) kepada DPR". ${ }^{52}$

Ada pula gagasan untuk tidak mengubah Pasal 5 ayat (1) UUD 1945 namun mengusulkan penambahan ayat dalam hal Presiden tidak mengesahkan RUU yang telah disetujui, maka dalam waktu satu bulan DPR berhak menetapkan berlakunya UU tersebut. ${ }^{53}$

Gagasan yang relevan dengan penegasan sistem presidensial juga berkembang pada pembahasan perubahan Pasal 5 ayat (1). Misalnya, Hamdan Zoelva dari F-PBB mengusulkan agar Pasal 5 ayat (1) diubah menjadi Presiden memberikan persetujuan atau menolak RUU yang telah ditetapkan DPR dalam waktu paling lama tiga puluh hari setelah diterimanya RUU. ${ }^{54}$ Selanjutnya Hamdan juga mengusulkan penambahan ayat yang rumusannya: "apabila telah melampaui tiga puluh hari Presiden tidak memberikan persetujuan atau menyatakan menolak maka RUU menjadi undang-undang seperti yang telah telah disetujui oleh DPR". ${ }^{55}$ Secara substansi, usulan tersebut sama dengan mekanisme pembentukan UU di AS, di mana Presiden hanya memiliki hak veto. Namun demikian, sebagian besar anggota MPR masih tetap menginginkan hak Presiden untuk mengajukan RUU tetap dipertahankan atau pembentukan UU merupakan kekuasaan bersama Presiden dan DPR. ${ }^{56}$

Setelah hampir semua fraksi mengarah untuk memberikan hak kepada Presiden mengajukan RUU, Hamdan Zoelva juga mengikuti pendapat mayoritas dengan menekankan bahwa yang diajukan oleh Presiden adalah RUU, bukan kekuasaan membentuk UU seperti pada naskah asli UUD $1945 .{ }^{57}$ Setelah dinamika pembahasan tersebut, semua fraksi secara aklamasi menyetujui rumusan Pasal 5 ayat (1) berubah menjadi "Presiden berhak mengajukan rancangan undang-undang kepada Dewan Perwakilan Rakyat". ${ }^{58}$ Perubahan terkait dengan fungsi legislasi tersebut merupakan pergeseran yang cukup fundamental. Sebelum perubahan,

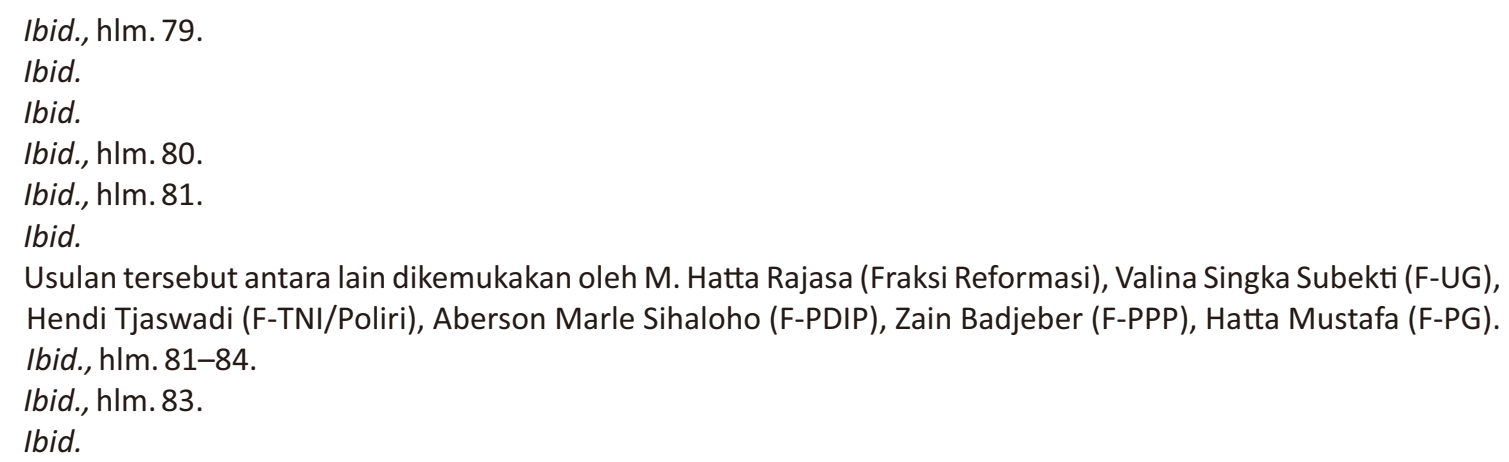


fungsi legislasi dipegang oleh Presiden, sedangkan setelah perubahan dipegang oleh DPR. ${ }^{59}$

Hak Presiden untuk mengajukan RUU kepada DPR sebenarnya masih relevan dengan gagasan sistem presidensial. Namun demikian, dalam pembahasan perubahan Pasal 20 UUD 1945, syarat mengenai adanya persetujuan bersama masih tetap dipertahankan, walaupun kekuasaan membentuk UU ditegaskan berada di tangan DPR. Semua fraksi di MPR menghendaki adanya persetujuan tersebut, baik terhadap RUU yang diajukan Presiden maupun RUU yang diajukan DPR. ${ }^{60}$

Adanya Pasal 20 ayat (1) dan Pasal 5 ayat (1) Perubahan Pertama UUD 1945 secara tekstual mengarah pada prinsip pemisahan kekuasaan dengan mekanisme check and balances. Sudah sewajarnya dalam sistem presidensial dipisahkan fungsi pembentukan UU dan pelaksanaan UU. Ditegaskannya kekuasan DPR membentuk UU sejalan dengan prinsip di atas, sementara hak Presiden untuk mengajukan RUU juga dianggap sebagai bagian dari prinsip check and balances system. Hal serupa juga ditemukan dalam Konstitusi AS di mana kekuasaan membentuk UU ada pada Congress, ${ }^{61}$ namun hak Presiden dalam pembentukan UU hanya diberikan secara implisit hanya untuk mengajukan usul RUU. ${ }^{62}$

Persoalannya, Pasal 20 ayat (2) Perubahan Pertama UUD 1945 menyatakan "Setiap rancangan undang-undang dibahas oleh Dewan Perwakilan Rakyat dan Presiden untuk mendapatkan persetujuan bersama". Dengan ketentuan tersebut maka perubahan yang dilakukan pada Pasal 5 ayat (1) dan Pasal 20 ayat (1) UUD 1945 menjadi tidak bermakna, karena secara substanstif kekuasaan pembentukan UU masih berada di tangan Presiden dan DPR secara bersama-sama (joint power). Hal tersebut juga tidak sesuai dengan prinsip pemisahan kekuasaan dan juga check and balances system.

Penambahan ayat (5) dalam Pasal 20 UUD 1945 yaitu dalam hal RUU yang telah disetujui bersama tersebut tidak disahkan oleh Presiden dalam waktu 30 hari semenjak RUU tersebut disetujui, RUU tersebut sah menjadi UU dan wajib diundangkan. Namun demikian, ketentuan tersebut tidak mencerminkan prinsip check and balances system, namun hanya ditujukan agar UU yang telah disetujui bersama pastiakan menjadi UU.
Rakyat", Padjadjaran Jurnal Ilmu Hukum, Volume 1, Nomor 1, 2014, hlm. 144.
lbid., hlm. 90-91.
61 Lihat Pasal 1 ayat (1) Konstitusi Amerika Serikat (Konstitusi AS).
62 Hak tersebut muncul dari penafsiran Pasal 3 Konstitusi. Menurut I Gde Panca Astawa, Presiden AS makin besar pengaruhnya baik dalam prakarsa maupun dalam pembuatan UU. I Gde Panca Astawa, "Identifikasi Masalah Atas Hasil Perubahan UUD 1945 Yang Dilakukan Oleh MPR dan Komisi Konstitusi", Makalah disampaikan dalam Seminar Reformasi Sistem Pemerintahan dan Sistem Ketatanegaraan: Antara UUD 1945 Hasil Amandemen dan Usul UUD 1945 Hasil Komisi Konstitusi, kerja sama FH Unpad-Persahi, Bandung, 23 September 2004, hlm. 12. 
Di AS, prinsip check and balances system tercermin dengan adanya hak veto dan counter veto, di mana Presiden dapat menolak untuk mengesahkan RUU yang telah disetujui Congress. Sebagai imbangannya, Congress dapat tetap memberlakukan RUU tersebut menjadi UU jika setelah veto Presiden, baik House of Representative maupun Senate bersepakat untuk menjadikannya UU dengan minimal suara $2 / 3$ dari masing-masing kamar. ${ }^{63} \mathrm{Di}$ negara presidensial lain, keterlibatan eksekutif dalam pembentukan sangat jarang dilembagakan.

Selain Indonesia, hanya ada 2 (dua) negara lagi yang memiliki wewenang konstitusional dalam proses legislasi, yaitu Chili dan Brazil, itu pun hanya dalam hal pengajuan RUU anggaran negara. ${ }^{64}$ Artinya jaminan konstitusional keterlibatan eksekutif presidensial dalam pembentukan undang-undang sangatlah jarang, berbeda dengan eksekutif parlementer yang-meminjam istilah Cheibub-memiliki kontrol tingkat tinggi (high degree of control) dalam proses legislasi. ${ }^{65}$ Dengan demikian, penegasan sistem Presidensial yang dimaksudkan dalam perubahan UUD 1945 tidak tercapai, karena pembentukan undang-undang lebih memperlihatkan pola diffusion (fusion) of power dalam sistem parlementer dibandingkan separation of power dalam sistem presidensial. ${ }^{66}$

Dari pemaparan di atas, khususnya dalam Perubahan Pertama UUD 1945 terdapat kecenderungan untuk membatasi kekuasaan Presiden. Namun demikian, seperti dikatakan oleh Ni'matul Huda bahwa pada Perubahan Ketiga UUD 1945, MPR justru menegaskan sistem pemerintahan Presidensial. ${ }^{67}$ Mungkin ini yang dikatakan oleh Sri Soemantri bahwa perubahan UUD 1945 tidak memiliki grand design. ${ }^{68}$

Terlepas dari tidak adanya grand design yang jelas dalam perubahan UUD 1945, namun ciri-ciri sistem presidensial tercermin khususnya dalam Pasal 6A ayat (1), Pasal 7A, 7B, 7C Perubahan Ketiga UUD 1945 mengenai pemilihan Presiden dan Wakil Presiden secara langsung dan pemberhentian Presiden dan Wakil Presiden dalam masa jabatannya atas alasan-alasan yang bersifat hukum, serta prinsip Presiden tidak dapat membekukan/membubarkan DPR. Pemilihan Presiden dan Wakil Presiden secara langsung memang sesuai dengan ciri sistem presidensial, walaupun di negara asal sistem ini (AS), dilakukan oleh badan pemilih (electoral college). Pemberhentian Presiden dan Wakil Presiden dalam masa jabatan atas

63 Lihat Pasal 1 ayat (7) Konstitusi AS.

64 Jose Antonio Cheibub, Op.cit., hIm. 101.

65 Ibid., hlm. 16.

66 Di Inggris sebagian besar RUU (public bill) berasal dari Pemerintah, sebagian kecil berasal dari anggota parlamen (private member's bill). I Gde Panca Astawa, Op.cit., hlm. 13.

67 Ni'matul Huda, Op.cit., hlm. 100.

68 Sri Soemantri, "Evaluasi Kritis Terhadap Amandemen UUD 1945", Makalah disampaikan dalam FGD Peran DPD Dalam Sistem Ketatanegaraan Indonesia, kerja sama Setjen DPD RI - Fakultas Hukum Unpad, Bandung 6 Agustus 2007, hlm. 5. 
dasar alasan yang bersifat hukum juga menjadi salah satu ciri sistem Presidensial yang dikenal dengan pranata impeachment ${ }^{69}$ atas dasar prinsip Presiden bertanggung jawab pada Konstitusi. ${ }^{70}$ Mengenai larangan Presiden untuk membekukan atau membubarkan DPR, merupakan salah satu konsekuensi dari sistem presidensial, akan tetapi seharusnya tidak perlu diatur secara eksplisit karena telah menjadi bagian dari sistem presidensial. ${ }^{71}$

Jika Perubahan Pertama UUD 1945 mencerminkan gagasan pembatasan Presiden dan cenderung pada legislative heavy, mengapa gagasan penerapan sistem parlementer tidak dipertimbangkan, namun justru sistem presidensial yang di-reafirmasi dalam Perubahan Ketiga UUD 1945?

Seperti telah dibahas sebelumnya bahwa walaupun semangat Perubahan Pertama UUD 1945 adalah untuk membatasi kekuasaan Presiden, namun semangat tersebut dimaksudkan untuk mewujudkan prinsip check and balances system. Terlepas pada akhirnya prinsip check and balances system tidak terwujud sepenuhnya dan masih mencerminkan aspek sistem parlementer, namun Perubahan Pertama UUD 1945 dilakukan dalam konteks sistem presidensial.

Gagasan sistem parlementer sendiri tidak pernah menjadi wacana konkret yang berkembang dalam Perubahan Pertama, apalagi dalam Perubahan Ketiga UUD 1945 di mana PAH I BP MPR bersepakat untuk menegaskan sistem presidensial. Tidak berkembangnya sistem parlementer dalam perubahan UUD 1945 lebih cenderung dipengaruhi oleh trauma penerapan sistem parlementer di masa lalu, sehingga menyebabkan pemerintahan yang tidak stabil. ${ }^{72}$ Padahal ketidakstabilan pemerintahan tidak hanya disebabkan oleh sistem parlementer saja, namun juga disebabkan karena faktor-faktor lain. Berbagai sistem parlementer dengan sistem multi partai atau bukan multi partai seperti di Inggris, Belgia, dan Belanda, dapat berjalan relatif stabil. ${ }^{73}$

Seperti telah dikemukakan pada bagian sebelumnya, ketidakstabilan pemerintahan juga pernah terjadi di Perancis pada masa Republik Kelima dan Keempat di mana rata-rata umur kabinet tidak lebih dari 6 (enam) bulan. ${ }^{74} \mathrm{Hal}$ tersebut salah satunya disebabkan karena sistem parlementer dikombinasikan dengan sistem multi partai. Namun demikian, di Jerman dan Belanda karena ketidakpuasan dalam

Perbedaan utamanya, di Indonesia proses pemberhentian Presiden dan Wakil Presiden melibatkan Mahkamah Konstitusi walaupun putusan akhir ada pada MPR, sementara impeachment di AS dilakukan secara langsung oleh Congress dengan House Representative sebagai penuntut dan Senate sebagai pemutus (juri).

71 Ketentuan tersebut berasal dari Penjelasan UUD 1945 dan praktik pembekuan/pembubaran DPR misalnya yang dilakukan oleh Presiden Abdurahman Wahid yang pernah mencoba untuk membekukan DPR dengan Maklumat Presiden 23 Juli 2001.

72 Lihat Bagir Manan, Teori dan Politik Konstitusi, Yogyakarta: FH UII Press, 2003, hlm. 6.

73 Bagir Manan, Lembaga...., Op.cit., hlm. 34.

74 Catherine Elliot (et. al.), Loc. cit., hlm. 14-15. 
sistem parlementer multi partai, maka setiap perubahan mendasar dalam komposisi kabinet harus dilakukan pemilihan ulang (anggota parlemen), ${ }^{75}$ sehingga sistem parlementer dapat kembali menciptakan stabilitas pemerintahan. Namun secara umum, kombinasi sistem parlementer dengan sistem multi partai tanpa adanya partai mayoritas dan koalisi yang permanen dapat menimbulkan ketidakstabilan pemerintahan.

Di Indonesia sendiri penyebab ketidakstabilan pemerintahan pada masa sistem parlementer selain disebabkan oleh penerapan sistem multi partai juga disebabkan oleh faktor-faktor lain, seperti dasar-dasar koalisi yang kurang kokoh, adanya kehendak menjalankan demokrasi secara berlebihan (ultra demokrasi), serta Presiden yang semestinya tidak ikut serta dalam politik pemerintahan melakukan berbagai tindakan yang mencampuri urusan penyelenggaraan pemerintahan. ${ }^{76}$ Ketidakstabilan pemerintahan pada masa sistem parlementer tidak hanya disebabkan oleh sistem pertanggungjawaban parlementer, seperti pada periode awal sistem parlementer diterapkan, jatuhnya kabinet tidak disebabkan secara langsung karena mosi tidak percaya Badan Pekerja Komite Nasional Indonesia Pusat (KNIP). ${ }^{77}$

Pengaruh negatif pertanggungjawaban parlementer dalam sistem multi partai terlihat pada masa berlakunya Undang-Undang Dasar Sementara 1950 (UUDS 1950), namun bercampur baur dengan faktor intervensi Presiden dalam kebijakan kabinet dan persoalan internal kabinet. Kabinet yang jatuh karena mosi parlemen adalah Kabinet Nasir (6 September 1950-27 April 1951), namun kejatuhan tersebut juga disebabkan oleh kegagalan dalam menyelesaikan persoalan Irian Barat sehingga mendapat tantangan dari Presiden Soekarno karena interpretasi yang sempit yang dianutnya terhadap kekuasaan Presiden. ${ }^{78}$

Sementara 2 (dua) mosi tidak percaya yang dilakukan parlemen kepada Kabinet Ali Sastroamidjojo (1 Agustus 1953-12 Agustus 1955) tidak berhasil menjatuhkan kabinet tersebut, melainkan kabinet tersebut jatuh akibat persoalan internal kabinet. ${ }^{79}$ Dengan demikian, penerapan sistem parlementer di masa lalu tidak sepenuhnya bersumber pada karakteristik sistem parlementer, namun lebih disebabkan sistem pemerintahan koalisi yang rentan dan kondisi pasca kemerdekaan yang belum sepenuhnya stabil di segala bidang.

Dalam hal ini, tidak dipertimbangkannya sistem parlementer dalam Perubahan UUD 1945 walaupun semangat berkembang dalam proses tersebut adalah pembatasan kekuasaan Presiden dan kencenderungan mengontrol Presiden, sangat mungkin disebabkan karena sistem presidensial dianggap sebagai salah satu

\footnotetext{
Lihat “Introduction”, Arend Lipjhart (eds), Loc.cit., hlm. 13.

Lihat Bagir Manan, Teori..., Op.cit., hlm. 7.

Lihat Ismail Suny, Op.cit., hlm. 64.

Ibid., hlm. 163.

Ibid., hlm. 164.
} 
identitas konstitusi (constitutional identity) Indonesia, termasuk juga akibat trauma terhadap kegagalan sistem parlementer di masa lalu. ${ }^{80}$ Sebagai identitas konstitusi, pilihan mempertegas sistem presidensial menjadi satu-satunya pilihan, mengingat penerapan sistem parlementer dikhawatirkan akan mengulang sejarah masa lalu.

$\mathrm{Hal}$ ini berbeda dengan pada saat Badan Penyelidik Usaha Persiapan Kemerdekaan (BPUPK) merancang UUD, di mana latar belakang perumusan sistem pemerintahan yang dianut sangat jelas. Seperti dikatakan oleh Seokiman dalam sidang BPUPK tanggal 15 Juli 1945 menanggapi rancangan Panitia Hukum Dasar, bahwa:

“...maka saya mufakat sekali Presiden dipilih oleh Majelis Permusyawaratan Rakyat (Pasal 4), ${ }^{81}$ dan buat sementara waktu tidak langsung oleh rakyat, buat sementara dengan kedudukan Presiden sebagai pembikin undang-undang biasa bersama dengan Dewan Perwakilan Rakyat dan para menteri-manteri bertanggungjawab kepadanya, tidak pada Dewan Perwakilan Rakyat, maka pemerintah secara parlementaire demokrasi Eropah tidak terpakai, yang saya sendiri amat setuju (Pasal 3). ${ }^{82}$ Dengan konstruksi demikian, maka terjaminlah tetap langsung stabiliteit pemerintahan yang sungguh menjadi syarat mutlak untuk membuat negara baru". ${ }^{83}$ (cetak tebal oleh Penulis)

Pandangan Soekiman di atas tidak secara eksplisit mencerminkan dianutnya sistem presidensial. Namun demikian, penolakan terhadap sistem parlementer, khususnya mengenai pertanggungjawaban menteri, mencerminkan sistem presidensial, walaupun semata-mata ditujukan sebagai 'sistem pemerintahan transisi yang stabil'. Di sisi lain, adanya kesepakatan untuk menegaskan sistem presidensial dalam perubahan UUD 1945 menunjukkan upaya reafirmasi sistem presidensial justru bersamaan dengan semangat pembatasan kekuasaan Presiden melalui penguatan kewenangan DPR yang justru menempatkan aspek sistem parlementer dalam sistem presidensial tanpa desain yang jelas.

80 Jacobsohn menegaskan bahwa identitas konstitusi muncul secara dialogis dan merepresentasikan campuran aspirasi politik dan komitmen sebagai ekspresi masa lalu sebuah bangsa yang dapat diubah tetapi tidak dapat dirusak, seperti larangan mengubah bentuk pemerintahan republik dalam Konstitusi Perancis 1958, komitmen Turki pada sekularisme. Lihat Gary Jeffrey Jacobsohn, Constitutional Identity, Cambridge, Massachusetts: Harvard University Press, 2010, hlm. 6-7.

81 Rancangan UUD dari Panitia Hukum Dasar Badan Penyelidik Usaha Persiapan Kemerdekaan (BPUPK).

82 Ibid.

83 A.B. Kusuma, Lahirnya Undang-Undang Dasar 1945, Jakarta: Badan Penerbit Fakultas Hukum Universitas Indonesia, 2004, hlm. 375. 


\section{Pertanggungjawaban Presiden dan Wakil Presiden Setelah Perubahan UUD 1945}

Perubahan konstitusi dapat mengubah sistem pertanggungjawaban pemerintah di suatu negara. Seorang teoritisi pertanggungjawaban, Herbert J. Spiro, mengatakan bahwa setiap sengketa pertanggungjawaban harus diselesaikan melalui proses dan jawaban yang telah ditentukan oleh konstitusi, Spiro menyatakan bahwa "The constitution is the structure of responsibility". ${ }^{84}$ Terlepas dari itu, tentu struktur pertanggungjawaban yang ditentukan oleh konstitusi harus pula sesuai dengan teori-teori pertanggungjawaban.

Sebelum membahas mengenai pertanggungjawaban Presiden dan Wakil Presiden dalam Konstitusi Indonesia, penting untuk dipahami terlebih dahulu makna dari pertanggungjawaban. Pertanggungjawaban merupakan istilah yang digunakan luas untuk berbagai makna bergantung pada konteks istilah tersebut digunakan. Herbert J. Spiro mengemukakan 3 (tiga) makna tanggung jawab (responsibility) yang berbeda namun saling terkait, yaitu tanggung jawab sebagai akuntabilitas (responsibility as accountability), tanggung jawab sebagai penyebab (responsibility as cause), dan tanggung jawab sebagai kewajiban (responsibility as obligation). ${ }^{85}$

Sebagai contoh, apabila dikatakan Menteri Luar Negeri (Menlu) Indonesia bertanggung jawab atas hubungan luar negeri, maka Menlu bertanggung jawab atau akuntabel (responsibility as accountability) terhadap jalannya urusan hubungan luar negeri Indonesia. Tanggung jawab (accountability) tersebut dapat eksplisit misalkan tugas dan fungsinya, atau implisit apabila tanggung jawab tersebut menjadi ada karena faktor di luar kuasanya yang tidak dapat diketahui sebelumnya. ${ }^{86}$ Tanggung jawab juga dapat dipandang sebagai penyebab (responsibility as cause), misalkan Menlu dikatakan bertanggung jawab atas baik atau buruknya hubungan Indonesia dengan Malaysia, hal tersebut karena apa yang dilakukan oleh Menlu mempengaruhi (contribute to) baik atau buruknya hubungan Indonesia dengan Malaysia. Sedangkan tanggung jawab sebagai kewajiban (responsibility as obligation), dapat diberi ilustrasi apabila Menteri bertanggung jawab (accountable) untuk menjalankan hubungan luar negeri, maka dia juga memiliki kewajiban untuk menjalankan hubungan tersebut. Tanggung jawab sebagai kewajiban akan berisi hubungan antara tanggung jawab sebagai penyebab dengan tanggung jawab dalam arti akuntabilitas. ${ }^{87}$

Berbicara pertanggungjawaban, terutama pertanggungjawaban dalam pemerintah, menurut Harun Al Rasyid terdapat 2 (dua) jenis pertanggungjawaban, yaitu

\footnotetext{
84 Herbert J.Spiro, Op.cit., hlm. 170.

85 Ibid., hlm. 14.

86 Contoh diadaptasi dari ilustrasi Herbert J. Spiro, Lihat Ibid., hlm. 14-23.

87 Ibid.
} 
pertanggungjawaban dalam arti luas dan pertanggungjawaban dalam arti sempit. ${ }^{88}$ Pertanggungjawaban dalam arti sempit ialah pertanggungjawaban tanpa sanksi, sedangkan pertanggungjawaban dalam arti luas merupakan suatu pertanggungjawaban dengan sanksi. ${ }^{89}$

Klasifikasi pertanggungjawaban lain yang perlu disampaikan terlebih dahulu adalah klasifikasi pertanggungjawaban menurut Herman Finer. Sarjana Politik dari Inggris tersebut membagi pertanggungjawaban menjadi 2 (dua), yakni pertanggungjawaban moral (moral responsibility) dan pertanggungjawaban politik (political/censorial responsibility). ${ }^{90}$ Pertanggungjawaban moral berarti bahwa standar penilaian tanggung jawab dan perilaku politisi (pejabat) ditentukan oleh dirinya sendiri atau lembaganya. Dalam hal ini, pihak lain tidak berhak memberi penilaian atau menentukan standar terhadap pelaksanaan tanggung jawabnya (tugas dan kewajiban). Sebaliknya, dalam pertanggungjawaban politik standar perilaku dalam bertindak sebagai pejabat dalam menjalankan tugasnya ditentukan dan dinilai oleh orang atau pihak lain.

Membicarakan perubahan UUD 1945 termasuk pada ketentuan mengenai pertanggungjawaban Presiden dan Wakil Presiden akan juga membicarakan mengenai sistem pemerintahan yang dianut. Hal tersebut karena sistem pemerintahan suatu negara menentukan bagaimana pertanggungjawaban pemerintah di negara tersebut dilakukan. ${ }^{91}$ Sebagaimana telah dikemukakan sebelumnya, dalam sistem pemerintahan parlementer, kabinet bertanggung jawab kepada parlemen. Pertanggungjawaban politik tersebut bermakna luas, karena parlemen dapat memberikan sanksi berupa mosi tidak percaya untuk memberhentikan pemerintah dengan alasan kebijakan atau alasan politik lainnya.

Di negara dengan sistem pemerintahan presidensial seperti Indonesia, pertanggungjawaban sebagaimana pada sistem pemerintahan parlementer tersebut tidak ada. Telah dikemukakan sebelumnya Presiden dalam sistem pemerintahan presidensial memiliki masa jabatan tetap dan tidak dapat diberhentikan pada masa jabatannya, kecuali melalui impeachment.

Setelah perubahan UUD 1945, Pasal 6A ayat (1) menentukan bahwa Presiden dan Wakil Presiden dipilih secara langsung oleh rakyat. Prinsip yang digunakan adalah popular vote, yang sedikit berbeda dengan electoral vote sebagaimana

88 Sri Soemantri, Tentang Lembaga-Lembaga Negara Menurut UUD 1945, Bandung: Citra Aditya Bakti, 1993, hlm. 121.

89 Ibid.

90 Herman Finer, The Major Governments of Modern Europe, New York, Evanston, dan London: Harper \& Row, Publishers, 1962, hlm. 5.

91 Bagir Manan menyatakan bahwa sistem pemerintahan berkaitan dengan tata cara pertanggungjawaban penyelenggaraan pemerintahan eksekutif dalam suatu tatanan negara demokrasi. Lihat Bagir Manan, Menyongsong Fajar Otonomi Daerah, Yogyakarta: Pusat Studi Hukum Fakultas Hukum Universitas Islam Indonesia, 2005, hlm. 250. 
dilakukan di AS. ${ }^{92}$ Pasal 7 mengatur mengenai Presiden dan Wakil Presiden memegang masa jabatan tetap selama 5 (lima) tahun, kemudian Pasal 7A dan Pasal 7B mengatur mengenai mekanisme impeachment bagi Presiden dan/atau Wakil Presiden.

Telah dibahas sebelumnya bahwa di negara dengan sistem pemerintahan presidensial, Presiden bertanggung jawab kepada Konstitusi melalui prosedur impeachment, selain bertanggung jawab kepada rakyat melalui pemilihan umum berikutnya. Mengenai impeachment, impeachment merupakan bentuk pertanggungjawaban hukum. Impeachment dilakukan atas dasar tuntutan pelanggaran hukum yang diatur dalam hukum (konstitusi) yang berbeda dengan pelaksanaan pengawasan politik kepada eksekutif sehari-hari dalam jabatannya. ${ }^{93}$ Oleh karena itu, impeachment yang dilakukan oleh badan perwakilan tidak berarti presiden bertanggung jawab kepada badan perwakilan tersebut.

Dasar yang dapat dijadikan alasan untuk memberhentikan Presiden dan/atau Wakil Presiden dalam masa jabatannya hanya terbatas apabila terbukti melakukan hal-hal sebagai berikut: ${ }^{94}$

1. Pelanggaran hukum berupa pengkhianatan terhadap negara, korupsi, penyuapan, tindak pidana berat lainnya; atau

2. Perbuatan tercela; maupun

3. Tidak lagi memenuhi syarat sebagai Presiden dan/atau Wakil Presiden.

Sementara itu di AS, alasan dilakukannya impeachment hanya berkisar pada 2 (dua) hal, yakni: ${ }^{95}$

1. Pelanggaran hukum berupa: treason (pengkhianatan negara), bribery (penyuapan), other high crimes (tindak pidana berat lainnya); dan

2. Misdemeanors (perbuatan tercela).

Terdapat perbedaan antara alasan-alasan melakukan impeachment pada UUD 1945 dan Konstitusi AS. Di AS, apabila Presiden atau Wakil Presiden tidak lagi memenuhi syarat sebagai Presiden atau Wakil Presiden, pemberhentiannya tidak dilakukan melalui impeachment. Amandemen ke-25 mengatur pranata tersendiri mengenai kekosongan dan ketidakmampuan pada jabatan kepresidenan, apabila Presiden berhalangan tetap maka Wakil Presiden dan mayoritas anggota kabinet

92 Kedua mekanisme ini sedikit berbeda. Dalam pemilihan langsung di Indonesia, Presiden dan Wakil Presiden ditentukan berdasarkan popular vote. Sementara di AS, walaupun electoral college hanya mentransfer suara pemilih pada calon Presiden dan Wakil Presiden yang diusung partai politik hasil konvensi, tetapi hasilnya tidak ditentukan oleh popular vote, melainkan melalui sistem electoral vote yang hasilnya sangat mungkin berbeda. Di AS, orang yang suara populernya (popular vote) lebih sedikit, bisa menjadi Presiden Amerika bila electoral vote-nya lebih banyak. Lihat R.M. A.B. Kusuma, "Presidensialisme Ala Indonesia", dalam Gagasan Amandemen UUD 1945 yang disusun oleh Mohammad Fajrul Falaakh (eds), Jakarta: KHN-RI, 2008, hlm. 200. Douglas V. Verney, “Parliamentary...., dalam Arend Lipjhart (eds), Op.cit., hlm. 43.

4 Lihat Pasal 7A Perubahan Ketiga UUD 1945.

95 Lihat Pasal 2 ayat (4) Konstitusi AS. 
menyampaikan pernyataan bahwa Presiden tidak mampu lagi melaksanakan tugas dan kewenangannya kepada Ketua Senate dan House of Representatives. ${ }^{96}$ Maka menjadi pertanyaan dalam UUD 1945 setelah perubahan, Presiden dan/atau Wakil Presiden yang tidak lagi memenuhi syarat sebagai Presiden dan/atau Wakil Presiden harus diberhentikan melalui prosedur impeachment.

Dari segi mekanismenya, Anibal-Perez Linan membedakan prosedur impeachment berdasarkan lembaga mana yang memutus impeachment. Prosedur congressional model of impeachment adalah apabila lembaga yang memutus adalah badan legislatif. Sedangkan apabila yang memutus adalah lembaga kehakiman, maka akan disebut judicial model of impeachment. Congressional model of impeachment dipraktikkan oleh AS yang mana House of Representative sebagai penuntut dan Senate sebagai pemutus. ${ }^{97}$ Sedangkan judicial model of impeachment dipraktikkan oleh Jerman, di mana impeachment terhadap Presiden dapat di-lakukan oleh Bundesrat atau Bundestag untuk diputus oleh Mahkamah Konstitusi. ${ }^{98}$

Di Indonesia, usul pemberhentian Presiden dan/atau Wakil Presiden yang dilakukan oleh DPR memang diputus pembuktiannya oleh Mahkamah Konstitusi (MK), namun putusan MK masih harus diputus oleh MPR. ${ }^{99}$ Oleh karena itu, putusan MK terhadap impeachment tidak mengikat sebagaimana praktik di Jerman atau Korea Selatan. ${ }^{100}$ Tidak jelas apa yang menjadi dasar MPR ketika memutus pelanggaran terhadap dasar impeachment yang telah dibuktikan oleh $\mathrm{MK}$, dikarenakan kewenangan tersebut dapat menjadi politis sekali.

Apabila dibandingkan terhadap praktik impeachment di AS yang dilakukan oleh Kongres, meskipun tergolong congressional model of impeachment, karena keputusan akhir impeachment ditentukan oleh badan legislatif, namun di persidangan impeachment yang dilakukan oleh Kongres AS sebenarnya merupakan persidangan peradilan perkara pidana atau perdata model AS, di mana Ketua MA berperan sebagai Hakim, House of Representatives sebagai Penuntut, dan Senate sebagai Juri. ${ }^{101}$ Mekanisme impeachment di Indonesia lebih mirip praktik di Nigeria, di mana dugaan impeachment diinisiasi oleh Majelis Nasional, diadili oleh panel

96 Mekanisme lebih lanjut dapat dilihat pada Amandemen Ke-25 Konstitusi AS. Lihat juga penjelasannya pada Kenneth R. Thomas dan Larry M. Eig (eds), The Constitution of the United States of America: Analysis and Interpretation (Centennial Edition), Washington: US Government Printing, 2014, hlm. 2279-2281.

97 Jika Presiden yang didakwa maka sidang impeachment dipimpin oleh Ketua Mahkamah Agung. Lihat Pasal 1 ayat (2) dan ayat (3) Konstitusi AS.

98 Bagir Manan, Lembaga..., Op.cit., hlm. 111.

99 Lihat Pasal 7A Perubahan Ketiga UUD 1945.

100 Di Korea Selatan, mosi impeachment dilakukan oleh Majelis Nasional dan diputus oleh Mahkamah Konstitusi. Putusan Mahkamah Konstitusi terhadap mosi impeachment bersifat final. Lihat Pasal 65 dan 113 Konstitusi Korea Selatan.

101 T. J. Hastead, "An Overview Of The Impeachment Process", Congressional Research Service (The Library Of Congress), http://www.senate.gov/reference/resources/pdf/98-806.pdf, diakses 26 Juni 2015. 
yang dibentuk oleh Ketua MA, kemudian apabila terbukti dikembalikan lagi kepada Majelis Nasional untuk diputus dengan resolusi minimal dua per tiga anggota agar impeachment dapat terjadi. ${ }^{102}$

Di AS yang memiliki pengalaman bernegara dengan sistem pemerintahan presidensial jauh lebih panjang dari Indonesia, praktik impeachment terhadap Presiden AS pernah dilakukan sebanyak 3 (tiga) kali, yaitu terhadap Presiden Andrew Johnson, Bill Clinton, dan Richard Nixon. Dari ketiga impeachment tersebut tidak pernah ada yang dianggap terbukti (conviction) oleh Senate. Tuntutan dari House of Representatives terhadap Presiden Andrew Johnson dan Bill Clinton tidak mendapatkan cukup suara dari anggota Senate selaku juri untuk menurunkan kedua Presiden tersebut dari jabatannya. Presiden Richard Nixon memilih mengundurkan diri dari jabatannya saat House of Representatives memulai investigasi terhadap keterlibatannya dalam skandal Watergate, sehingga proses impeachment tidak dilanjutkan lagi. ${ }^{103}$ Impeachment memang sangat sukar terjadi di negara dengan sistem pemerintahan presidensial.

Mengenai pertangungjawaban politik dalam sistem presidensial, eksekutif bertanggung jawab secara langsung kepada pemilihnya. ${ }^{104}$ Eksekutif dalam sistem presidensial bergantung pada suara pemilih di mana Presiden dan/atau Wakil Presiden dipilih oleh keseluruhan pemilih. ${ }^{105}$ Pandangan ini tidak terlepas dari pemikiran Herbert J. Spiro yang menyatakan bahwa "anyone who exercises delegated responsibility should be accountable to the sources from which he derives his causal capacity". Spiro juga menyatakan "in the case of the President of the United States, it means accountability to the source of his delegated responsibility, the national electrorate". ${ }^{106}$ Oleh karena itu, dalam sistem pemerintahan presidensial, kekuasaan Presiden bersumber dari rakyat yang memilihnya, maka disimpulkan Presiden bertanggung jawab secara politik kepada rakyat.

Pertanggungjawaban Presiden kepada rakyat menggunakan pemilu sebagai media. Penilaian rakyat terhadap kinerja Presiden dalam pemilu akan menentukan apakah Presiden akan terpilih kembali pada masa jabatan kedua atau tidak. Apabila Presiden tidak dipilih kembali hal tersebut dipandang sebagai sanksi dari rakyat kepada Presiden. Persoalannya, pertanggungjawaban dengan cara ini tidak relevan jika Presiden sudah berada pada masa jabatan kedua. Penilaian rakyat kepada Presiden tidak memiliki konsekuensi apa pun, karena pasangan tersebut tidak

102 Pasal 143 Konstitusi Nigeria.

103 Kenneth R. Thomas dan Larry M. Eig (eds), Op.cit., hlm. 625-631. Baca juga "Notable Impeachment Proceeding" dalam John Murphy, Op.cit., hlm. 54-77.

104 "The executive is directly responsible yo the electorate". Ibid, hlm. 45. "Responsibility of governments to their electorates", Herbert J. Spiro, Op.cit., hlm. 4.

105 Douglas V. Verney dalam Arend Lipjhart (eds), Op.cit., hlm. 45.

106 Herbert J.Spiro, Op. cit., hlm. 142 dan 169. 
memiliki kesempatan lagi untuk mengikuti pemilu. Pertanggungjawaban ini juga tidak relevan apabila Presiden yang telah menyelesaikan masa jabatannya yang pertama tidak berniat mencalonkan kembali dalam pemilihan presiden berikutnya.

Meskipun utopia, namun keadaan tersebut realistis untuk terjadi. Dengan konstruksi pikir demikian, pertanggungjawaban Presiden melalui pemilu bersifat kondisional (tidak mutlak) karena bergantung pada pencalonan kembali Presiden pada pemilu untuk masa jabatan kedua. Setelah masa jabatan kedua selesai, pemilu tidak dapat digunakan untuk menilai pertanggungjawaban pasangan Presiden tersebut.

Uraian mengenai pertanggungjawaban hukum melalui impeachment dan pertanggungjawaban politik melalui pemilu menunjukan bahwa dalam sistem pemerintahan presidensial pertanggungjawaban dengan sanksi sangat dibatasi. Sistem pemerintahan presidensial memang memberikan kekuasaan kepada eksekutif untuk tidak diberhentikan selama masa jabatannya, namun dengan adanya check and balances, stabilitas pemerintahan (stability of government) dan pemerintahan yang terbatas (limited government) memang keuntungan dari sistem pemerintahan presidensial sebagaimana dikutip dari Liphart sebelumnya.

Di samping keterbatasan pertanggungjawaban dengan sanksi dalam struktur UUD 1945 setelah perubahan, perubahan pertama UUD 1945 melembagakan instrumen pengawasan badan legislatif melalui Pasal 20A. Pasal tersebut melembagakan hak pengawasan DPR dengan instrumen hak interpelasi, hak angket, dan hak menyatakan pendapat. ${ }^{107}$ Pelembagaan ketiga instrumen pengawasan tersebut oleh sebagian orang dipandang sebagai ciri sistem pemerintahan parlementer. Pandangan tersebut dapat dipahami, karena apabila kita menilik sejarah konstitusi Indonesia, maka hak interpelasi, hak angket, dan hak menyatakan pendapat pertama kali muncul pada saat Indonesia memberlakukan sistem pemerintahan parlementer. ${ }^{108}$

Hak interpelasi dan hak angket sendiri pernah ditemui dalam UUD Republik Indonesia Serikat (RIS) dan UUDS 1950. Pasal 120 ayat (1) UUD RIS menyatakan bahwa DPR mempunyai hak interpelasi dan hak menanya, dan Pasal 121 UUD RIS menyatakan bahwa DPR mempunyai hak menyelidiki (enquete). Sementara itu, pada Pasal 69 ayat (1) UUDS 1950 menyatakan bahwa DPR mempunyai hak

107 Dikatakan melembagakan karena menurut Hamdan Zoelva sebelum UUD 1945 diubah pun DPR telah memiliki kewenangan untuk melakukan pengawasan terhadap Pemerintah yang secara ringkas diatur dalam Penjelasan UUD 1945. Lihat Tim Penyusun Naskah Komprehensif Proses dan Hasil Perubahan UUD 1945, “Naskah Komprehensif Perubahan Undang-Undang Dasar Negara Republik Indonesia Tahun 1945, Buku III Lembaga Permusyawaratan dan Perwakilan Jilid 2", Jakarta: Sekretariat Jenderal dan Kepaniteraan Mahkamah Konstitusi, 2010, hlm. 1001.

108 Ali Abdurahman, "Hubungan Antara Presiden dan Dewan Perwakilan Rakyat Dalam Sistem Pemerintahan Menurut Perubahan UUD 1945", Disertasi, Bandung: Fakultas Hukum Universitas Padjadjaran, 2011, hlm. 283. 
interpelasi dan hak menanya, dan Pasal 710 menyatakan bahwa DPR mempunyai hak menyelidiki (enquete). Meskipun demikian, secara substantif pengawasan dengan bentuk demikian juga umum pada sistem pemerintahan presidensial (dengan peristilahan yang beragam). Di AS sendiri, memang fungsi pengawasan tidak secara eksplisit dicantumkan dalam konstitusi, namun fungsi tersebut dijalankan oleh Kongres sebagai implied power dari fungsi legislasi dan fungsi anggaran. Fungsi pengawasan tersebut secara prosedur diatur dalam beberapa undang-undang sektor.

Dalam praktik fungsi pengawasan yang dilakukan oleh Kongres, terdapat bentuk penyelidikan (investigative) yang pada prinsipnya memiliki tujuan yang sama dengan hak angket. Dalam perkara Watkins v. United States, Pengadilan berpendapat "power of the Congress to conduct investigations is inherent in the legislative process. That power is broad. It encompasses inquiries concerning the administration of existing laws as well as proposed or possibly needed statutes". Pengadilan juga berpendapat bahwa Kongres memiliki kewenangan melakukan penyelidikan dan mempublikasikan kasus korupsi, maladministrasi, atau inefisiensi pada badan pemerintahan. ${ }^{109} \mathrm{Hal}$ tersebut menunjukan bahwa Kongres Federal AS memiliki sekaligus kewenangan untuk interpelasi (bertanya), angket (penyelidikan), dan menyatakan pendapat.

Meskipun tidak memiliki sanksi, namun fungsi pengawasan ini dapat berjalan sistematis dengan fungsi legislasi dan anggaran. Mantan Hakim Agung AS Van Devanter menyatakan bahwa fungsi pengawasan merupakan penunjang esensial terhadap fungsi legislasi. ${ }^{110}$ Menurut Andrew Beale, fungsi pengawasan juga merupakan penunjang yang dapat digunakan untuk mengawasi penggunaan anggaran oleh pemerintah. ${ }^{111}$ Sebaliknya, fungsi legislasi dan fungsi anggaran dapat digunakan untuk memperkuat fungsi pengawasan DPR. Meskipun bukan sebagai bentuk sanksi, akan tetapi dapat saja dalam pembahasan anggaran tahun selanjutnya DPR menolak anggaran tertentu atas dasar ketidaksetujuan DPR terhadap pilihan kebijakan pemerintah terkait anggaran tersebut. Dalam praktik, kasus Watergate yang menyebabkan pengunduran diri Richard Nixon setelah di-impeach oleh House of Representatives merupakan hasil dari pengawasan investigatif oleh Kongres. ${ }^{112}$

Apabila berbicara mengenai pertanggungjawaban, memang sistem presidensial yang bertujuan menciptakan pemerintahan yang stabil berbanding terbalik dengan prinsip pemerintahan yang bertanggung jawab (responsible government)

109 Elissa M. Dolan (et. al.), Congressional Oversight Manual, CRS 7-5700, www.crs.gov

110 Kenneth R. Thomas dan Larry M. Eig (eds), The Constitution of The United States Of America: Analysis and Interpretation (Centennial Edition), Washington: U. S. Government Printing, 2014, hlm. 94.

111 Ibid., hlm. 242-243.

112 Morton Rosenberg, "Investigative Oversight: an Introduction to the Law, Practice and Procedure of Congressional Inquiry", CRS-7-5700, 1995, https://www.fas.org/sgp/crs/misc/95-464.pdf 
yang berkembang di sistem pemerintahan parlementer. Pengawasan oleh DPR tidak dapat menjawab pertanggungjawaban politik presiden apabila presiden kehilangan kepercayaan dari rakyat. Sistem presidensial lebih me-nampakkan pertanggungjawaban yang sifatnya moral, karena walaupun standar perilaku (dalam hal ini kekuasaan) Presiden ditentukan dalam UUD 1945 maupun UU, namun kedudukan Presiden tidak dapat diganggu oleh lembaga lain. Kondisi ini merupakan konsekuensi dari reafirmasi sistem pemerintahan presidensial setelah perubahan UUD 1945.

\section{E. Penutup}

Dari pembahasan di atas, penulis menarik 2 (dua) kesimpulan utama. Pertama, reafirmasi sistem presidensial dalam UUD 1945 yang ditegaskan dalam Perubahan Ketiga UUD 1945 dilatarbelakangi oleh semangat membentuk pemerintahan yang stabil, sekaligus juga semangat pembatasan kekuasaan Presiden yang justru menginginkan legislatif memiliki peran lebih dari sebelumnya atau dengan kata lain lebih mengarah pada sistem parlementer. Namun demikian, pengalaman masa lalu yang tidak sukses dalam menerapkan sistem parlementer menyebabkan Perubahan UUD 1945 mereafirmasi sistem presidensial, sebagai salah satu identitas konstitusi, namun masih tercampuraduk dengan pranata parlementer, khususnya dalam hal pembentukan UU. Kedua, perubahan pola UUD 1945 juga berkonsekuensi pada perubahan mekanisme pertanggungjawaban Presiden dan Wakil Presiden. Pertanggungjawaban dengan sanksi dalam sistem pemerintahan Indonesia setelah perubahan UUD 1945 sangat terbatas. Pertanggungjawaban hukum melalui impeachment memiliki syarat dan prosedur ketat sehingga sukar terjadi. Pertanggungjawaban politik Presiden secara implisit dilakukan melalui pemilu juga terbatas pada saat Presiden mencalonkan diri kembali pada pemilu untuk masa jabatan kedua. Pengawasan oleh DPR dapat berpengaruh kepada pilihan kebijakan, namun tetap memiliki keterbatasan sanksi sehingga Presiden setelah perubahan UUD 1945 memiliki stabilitas dalam menjalankan masa jabatannya.

\section{Daftar Pustaka}

\section{Buku}

A.B. Kusuma, Lahirnya Undang-Undang Dasar 1945, Badan Penerbit Fakultas Hukum Universitas Indonesia, Jakarta, 2004.

Bagir Manan, DPR, DPD dan MPR Dalam UUD 1945 Baru, FH UII Press, 2004. , Lembaga Kepresidenan, edisi revisi, FH UII Press, Yogyakarta, 2003. , Menyongsong Fajar Otonomi Daerah, Pusat Studi Hukum Fakultas

Hukum Universitas Islam Indonesia, Yogyakarta, 2005. , Teori dan Politik Konstitusi, FH UII Press, Yogyakarta, 2003. 
Cheibub, Jose Antonio, Presidentialism, Parliamentarism, and Democracy, Cambridge University Press, Cambridge, 2006.

Dahl, Robert A. (et.al.) (eds), The Democracy Source Book, The MIT Press, Cambrige, 2003.

Elliot, Catherine (et.al.), French Legal System, Pearson Education Limited, England, 2006.

Finer, Herman, The Major Governments of Modern Europe, Harper \& Row, Publishers, New York, Evanston, and London, 1962.

Ismail Suny, Pergeseran Kekuasaan Eksekutif Suatu Penyelidikan Dalam Hukum Tata Negara, Aksara Baru, Jakarta, 1981.

Jacobsohn, Gary Jeffrey, Constitutional Identity, Harvard University Press, Cambridge, Massachusetts, 2010.

Koerniatmanto Soetoprawiro, Hukum Kewarganegaraan dan Keimigrasian Indonesia, Gramedia Pustaka Utama, Jakarta, 1994.

Lipjhart, Arend (eds), Parliamentary Versus Presidential Government, Oxford University Press, New York, 1992.

Mohammad Fajrul Falaakh (eds), Gagasan Amandemen UUD 1945, KHN-RI, Jakarta, 2008.

Ni'matul Huda, Politik Ketatanegaran Indonesia Kajian Terhadap Dinamika Perubahan UUD 1945, FH UII Press, Yogyakarta, 2003.

Spiro, Herbert J, Responsibility in Government: Theory and Practice, Van Nostrand Reinhold Company, New York, 1969.

Sri Soemantri, Sistem-Sistem Pemerintahan Negara-Negara ASEAN, Penerbit Tarsito, Bandung, 1976.

, Tentang Lembaga-Lembaga Negara Menurut UUD 1945, Citra Aditya Bakti, Bandung, 1993.

Thomas, Kenneth R. dan Larry M. Eig (eds), The Constitution of the United States of America: Analysis and Interpretation (Centennial Edition), US Government Printing, Washington, 2014.

Tim Penyusun, Naskah Komprehensif Perubahan Undang-Undang Dasar Negara Republik Indonesia Tahun 1945: Latar Belakang, Proses, dan Hasil Pembahasan 1999-2002, Setjen MK-RI, Jakarta, 2008.

Woll, Peter, American Government, Random House, New York, 1989.

\section{Dokumen Lain}

Ali Abdurahman, "Hubungan Antara Presiden dan Dewan Perwakilan Rakyat Dalam Sistem Pemerintahan Menurut Perubahan UUD 1945", Disertasi, Fakultas Hukum Universitas Padjadjaran, Bandung, 2011.

Bagir Manan, "Beberapa Persoalan Paradigma Setelah atau Akibat Perubahan UUD 1945”, Jurnal Konstitusi PSKN FH Unpad, Volume II, Nomor 2, 2010. 
Bilal Dewansyah, "Pertanggungjawaban Wakil Presiden Dalam Sistem Pemerintahan Indonesia Setelah Perubahan UUD 1945", Skripsi, Fakultas Hukum Universitas Padjadjaran, 2006.

Hernadi Affandi, "Problematika Fungsi Legislasi Dewan Perwakilan Daerah dalam Hegemoni Dewan Perwakilan Rakyat", Padjadjaran Jurnal IImu Hukum, Volume 1, Nomor 1, 2014.

I Gde Panca Astawa, "Identifikasi Masalah Atas Hasil Perubahan UUD 1945 Yang Dilakukan Oleh MPR dan Komisi Konstitusi", Makalah disampaikan dalam Seminar Refromasi Sistem Pemerintahan dan Sistem Ketatanegaraan: Antara UUD 1945 Hasil Amandemen dan Usul UUD 1945 Hasil Komisi Konstitusi, kerja sama FH Unpad-Persahi, Bandung, 23 September 2004.

Rosenberg, Morton, "Investigative Oversight: an Introduction to the Law, Practice and Procedure of Congressional Inquiry", CRS-7-5700, 1995, https://www.fas.org/sgp/crs/misc/95-464.pdf

Setjen MPR RI, "Panduan Pemasyarakatan Undang-Undang Dasar Negara Republik Indonesia 1945", Setjen MPR RI, Jakarta, 2006.

Sri Soemantri, "Evaluasi Kritis Terhadap Amandemen UUD 1945", Makalah disampaikan dalam FGD Peran DPD Dalam Sistem Ketatanegaraan Indonesia, kerja sama Setjen DPD RI-Fakultas Hukum Universitas Padjadjaran, Bandung 6 Agustus 2007.

\section{Dokumen Hukum}

Undang-Undang Dasar Republik Indonesia 1945 (sebelum dan setelah perubahan). Konstitusi Amerika Serikat.

Konstitusi Korea Selatan. 